\title{
SECRETORY PROTEIN SYNTHESIS IN PAROTID GLANDS OF YOUNG AND OLD RATS
}

\author{
S.-K. KIM and DEBBY W. C'ALKINS \\ Research Service, V.A. Medical Center, Ann Arbor, MI 48105 and Department of Anatomy. \\ The University of Michigan Medical School, Ann Arbor, MI 48109. U.S.A.
}

\begin{abstract}
Summary--To determine whether the synthesis of secretory proteins changes with age, the incorporation of $\left[{ }^{14} \mathrm{C}\right]$-leucine into exportable proteins of the parotid gland was compared in 2- and 24-month-old rats. The proteins were separated by SDS-gel electrophoresis of the post-microsomal supernatant and identified by comparing the banding patterns in gels prepared from unstimulated glands with those from the glands stimulated to secrete. The amount of radioactivity incorporated into the bands corresponding to exportable proteins was significantly less in the older group, indicating that the synthesis of secretory proteins declines with age.
\end{abstract}

\section{INTRODUCTION}

Some aspects of salivary gland function undergo changes with increasing age in man. In elderly persons, the amylase content (Meyer et al., 1937; Meyer and Necheles, 1940; Chilla et al., 1974), as well as the secretion and flow rate (Necheles, Plotke and Meyer, 1942; Bertram, 1967) of the saliva, is considerably reduced. The reduced level of amylase content and secretion of saliva suggests that the cellular level of secretory proteins is reduced with age, possibly due to the reduction in the synthesis of these proteins in salivary glands.

We have shown that the rate of protein synthesis declines progressively with age in parotid glands of the rat (Kim et al.. 1980, 1981; Kim, 1981). In these glands, the rate of incorporation of $\left[{ }^{3} \mathrm{H}\right]$-leucine into the acid-insoluble proteins declines with increasing age. However, it has not been reported previously whether the synthesis of exportable, secretory proteins of the salivary gland is affected by ageing. We here report that the synthesis of these proteins is reduced with age in parotid glands of the rat.

\section{MATERIALS AND METHODS}

\section{Animals}

Male Sprague-Dawley rats were obtained from Charles River Breeding Laboratories, Portage, Mich. The young rats were about 2 months old and weighed $200-250 \mathrm{~g}$. The old rats were $23-25$ months old and came from the ageing colony maintained at the breeder. They weighed about $550-650 \mathrm{~g}$. All animals were Caesarean-derived and maintained behind a barrier-containment facility. The rats showed negative titres for sialodacryoadenitis (SDA) viruses which affect the structure and function of salivary glands' and are widespread in other commercially available rats. Food was withheld for about $16 \mathrm{~h}$ before experiments. Rats were killed between 8 and 9 a.m. by cervical dislocation.

\section{Electrophoresis and radioactivity determinations}

Labelling with $\mathrm{L}-U-\left[{ }^{14} \mathrm{C}\right]$-leucine. The detailed procedures for labelling with the amino acid have been described previously (Kim et al.. 1980, 1981; Kim,
1981). Parotid slices were incubated in minimum essential medium (MEM, Gibco Laboratories. Grand Island, N.Y.) without leucine supplemented with the radioactive leucine $(9 \mu \mathrm{Ci} / \mathrm{ml}$; sp. act. $351 \mathrm{mCi} / \mathrm{mmol}$, Amersham, Arlington Heights, Ill.). Slices were incubated for $60 \mathrm{~min}$ at $37^{\circ} \mathrm{C}$ with constant agitation $(80$ cycles/min) and continuous gassing (95 per cent $\mathrm{O}_{2}$ and 5 per cent $\mathrm{CO}_{2}$ ). After incubation, gland slices were homogenized in phosphate-buffered saline (PBS) containing $0.3 \mathrm{M}$ sucrose $(10: 1, \mathrm{v} / \mathrm{w})$, and the postmicrosomal supernatant (PMS) was obtained through a series of centrifugations as described by Amsterdam et al. (1971).

Gel electrophoresis. Sodium dodecyl sulphate (SDS)-gel electrophoresis was performed by a procedure modified from that described by Keleti and Lederer (1974). After determination of the protein cohtent (Lowry, et al., 1951), samples equivalent to $30 \mu \mathrm{g}$ protein were loaded on the surface of the 10 per cent polyacrylamide gel. Electrophoresis was carried out for $6 \mathrm{~h}$ at $7 \mathrm{~mA} /$ tube in 12-place vertical gelcolumn cells using $0.1 \mathrm{M}$ sodium-phosphate huffer containing 1 per cent SDS as an electrode buffer. The gels were then stained with 0.25 per cent Coomassic Brilliant Blue R for $8 \mathrm{~h}$ and de-stained in a solution containing 20 per cent ethanol and 7 per cent glacial acetic acid for $36 \mathrm{~h}$. The de-staining solution was changed every $8 \mathrm{~h}$.

Radioactivity determinations. After gels had been stained and de-stained. they were scanned on a Beckman spectrophotometer modified with a Gilford linear-transport system. The gels were then frozen on dry ice and serially sliced into $0.5 \mathrm{~mm}$ sections on a Mickle gel slicer. Frozen slices from each gel were reconstructed by placing the sections side by side in a moist Petri dish. When the gel had thawed. the slices making up the bands were plucked from the gel and the protein content was quantitated according to the dye elution method of Fenner et al. (1975). The absorbance $(605 \mathrm{~nm})$ of a $1-\mathrm{ml}$ volume of each supernatant containing the eluted dye was determined and the total absorbance for a sample was calculated as $A_{605} / \mathrm{ml} \times \mathrm{ml} / \mathrm{sample}$. There was a direct correlation between the absorption of dye units and the amount of protein loaded on the gel. 
The $1 \mathrm{ml}$ sample of supernatant used for absorbance measurement was pipetted back into its respects ive tube which was then vortexed vigorously. Samples of $0.2 \mathrm{ml}$ were withdrawn, digested at $50^{\circ} \mathrm{C}$ in waterNCS (Amersham) mixture and radioactivity counted. Radioactivity in each band of the two age groups was counted in a Beckman LS 9000 liquid scintillation spectrophotometer and compared based on dis. $/ \mathrm{min} / A_{605}$ unit.

\section{Identification of secretory proteins}

The $\alpha$-amylase and other secretory proteins of the gland, separated by SDS-gel electrophoresis of the water-soluble proteins from the post-microsomal fraction, were identified by the following methods.

Isoproterenol-stimulated secretion. A single injection of isoproterenol (IPR) (Sigma, St Louis, Mo., $0.8 \mathrm{mg} / 100 \mathrm{~g}$ body $w \mathrm{t})$ induces a near complete discharge of the stored secretory product from the rat parotid gland within $1 \mathrm{~h}$ (Amsterdam et al., 1972; Lillie and Han, 1973). The PMS fractions of the stimulated glands were obtained from the rats $1 \mathrm{~h}$ after the intraperitoneal injection of IPR and were subjected to SDS-gel electrophoresis as described above. The $x$-amylase activity in the stimulated gland, assayed by the amylochrome method (Lillie and Han, 1973), was reduced by 98 per cent as compared with the unstimulated controls. The bands corresponding to secretory proteins were either reduced in width or absent in gels prepared with the PMS from the stimulated glands.

In-vitro IPR-stimulation of parotid lobules. Parotid lobules were isolated with fine-tipped forceps and incubated in MEM containing $10^{-5} \mathrm{M}$ IPR to induce secretion. The incubation was carried out for $2 \mathrm{~h}$ at $37^{\circ} \mathrm{C}$ with continuous gassing. After incubation, the medium was collected, dialysed $72 \mathrm{~h}$ against PBS and subjected to SDS-gel electrophoresis to separate secreted proteins.

\section{RESULTS}

The water-soluble proteins of the PMS separated into bands upon electrophoresis on SDS-polyacrylamide gels and staining with Coomassie Brilliant Blue $\mathrm{R}$ (Fig. 1). The banding patterns of the gel preparations from the glands of 2- and 24-month-old rats were, nearly identical except for slight differences in staining intensity (Fig. I, $\mathrm{Y}$ and $\mathrm{O}$ ).

The bands corresponding to exportable, secretory proteins were identified by comparing the gel preparations from the unstimulated glands with those from the glands stimulated to secrete by an injection of IPR or by incubating with the secretogogue. The $x$-amylase activity was reduced by 98 per cent of the unstimulated level in the glands of the rats which had been injected with IPR $1 \mathrm{~h}$ prior to killing. In gel preparations of these stimulated glands (Fig. 1S), the bands corresponding to secretory proteins were either absent or reduced in width and staining intensity (those bands labelled as $S_{1}-S_{5}$ ). Although these bands of proteins were not identified, the band $\mathrm{S}_{5}$ comigrated with $\alpha$-amylase from porcine pancreas (obtained from Sigma; Fig. 1A).

Furthermore, the bands $S_{1}-S_{5}$ were distinct in gels prepared with the MEM in which parotid lobules had been incubated in the presence of $10^{-5} \mathrm{M}$ IPR (Fig.
IM). The incubation of the parotid lobules with IPR resulted in a 65 per cent release of $\alpha$-amylase from the tissue.

The spectrophotometric scans of the stained gels and the radioactivity determinations in serial sections of these gels showed that the radioactivity peaks coincided with the peaks of staining intensity in both age groups (results not shown). The level of radioactivity incorporated into each of these secretory protein bands was significantly lower $(p \leq 0.05)$ in the older age group as compared with that in the younger group (Table 1). The mean ratio of the radioactivity
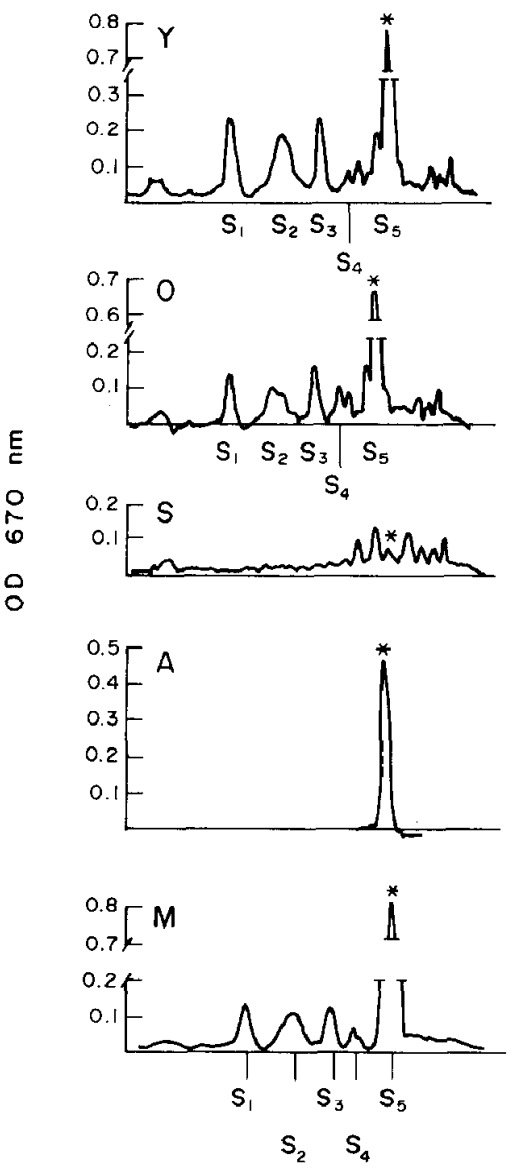

Fig. 1. Densitometric tracing of the parotid gland proteins stained with Coomassie Brilliant Blue $\mathbf{R}$ following the separation by SDS-polyacrylamide gel electrophoresis. The gels were scanned at $670 \mathrm{~nm}$ on a Beckman spectrophotometer modified with Gilford linear transport system at $1 \mathrm{~cm} / \mathrm{min}$ with charting speed of $2 \mathrm{~cm} / \mathrm{min}$. Water-soluble proteins of the post-microsomal supernatant from the glands of 2-(Y) and 24-(O) month-old rats form near identical banding patterns. The bands, labelled $S_{1}-S_{5}$, are identified as those corresponding to the exportable, secretory proteins of the gland. These bands are either absent or reduced in width and staining intensity in gels prepared with the glands which were stimulated to secrete nearly all the stored proteins by an injection of isoproterenol (S). On the other hand, these bands are very distinct in gels prepared with the medium in which parotid lobules were induced to secrete proteins by incubating with isoproterenol $(M)$. One of these proteins, $S_{5}$ (also indicated by an asterisk), co-migrates with $\alpha$-amylase from porcine pancreas (obtained commercially), as shown in A. 
Table 1. Incorporation of $\left[{ }^{14} \mathrm{C}\right]$-leucine into bands of secretory protein separated by SDS-gel electrophoresis of post-microsomal water-soluble proteins from parotid glands

\begin{tabular}{|c|c|c|c|}
\hline $\begin{array}{c}\text { Band } \\
\text { number }\end{array}$ & $\begin{array}{l}\mathrm{dis} \cdot / \min / A_{60} \\
2 \text { months }\end{array}$ & $\begin{array}{l}=\mathrm{SE}\left(\times 10^{3}\right) \\
\quad 24 \text { months }\end{array}$ & $\begin{array}{c}\text { Ratio } \\
24 \text { months/ } \\
2 \text { months }\end{array}$ \\
\hline S1 & $57.07 \pm 2.74(10)$ & $43.42 \pm 2.66(10)$ & 0.761 \\
\hline $\mathrm{S} 2$ & $9.17 \pm 0.89(9)$ & $7.50 \pm 0.53(10)$ & 0.818 \\
\hline S3 & $11.64 \pm 0.90(10)$ & $8.83 \pm 0.69(10)$ & 0.758 \\
\hline S4 & $9.56 \pm 0.83(4)$ & $4.99 \pm 0.68(4)$ & 0.661 \\
\hline S5 & $13.09 \pm 0.64(6)$ & $10.62 \pm 0.26(6)$ & 0.811 \\
\hline
\end{tabular}

The number of samples is given in parentheses.

incorporation in these bands of the two age groups (24 months/2 months) was 0.762 .

\section{DISCLSSION}

The water-soluble proteins in the PMS of the gland from the 2- and 24-month-old rats formed nearly identical banding patterns on the SDS-gels, indicating that the protein composition of this gland did not change significantly with age. Despite this, the synthesis of, at least, some of these proteins appears to decline with age. The lower level of $\left[{ }^{14} \mathrm{C}\right]$-leucine incorporation into the bands, labelled $S_{1}-S_{5}$, indicates that the synthesis of secretory proteins declines with increasing age. Although the bands were not identified individually except for the band $\left(\mathrm{S}_{5}\right)$ corresponding to $\alpha$-amylase. it is likely that they are made up of exportable, secretory proteins. The proteins in these 5 bands were reduced in concentration in the glands after the IPR-stimulated secretion and present in high concentration in the medium after incubating the lobules with IPR.

These results are consistent with our previous findings based on the incorporation studies of leucine into acid-insoluble. total proteins of the gland (Kim et al.. 1980. 1981: Kim. 1981). Furthermore, age-related reductions in the synthesis of proteins in many organs and tissues have been reported previously (Breuer and Florini. 1965: Murthy and Rappoport, 1965; Hrachovec. 1969; Johnson and Belytschko, 1969: Mainwaring, 1969; Kurtz, 1975; Layman, Ricca and Richardson, 1976; Liul et al. 1978; Moldave et al., 1979).

It remains uncertain whether the synthesis of all cellular proteins is uniformly affected. In the livers of rats (Ove, Obenrader and Lansing, 1972; Du. Beyer and Lang, 1977: van Bezooijen. Grell and Knook. 1977) and mice (Du e't al. 1977) the synthesis of albumin increases with age, the synthesis of ferritin does not change, while that of haem protein declines. These results suggest that the synthesis of proteins with different functions is affected during ageing depending on the needs for the proteins. This appears to be the case in parotid glands of the rat. The synthesis of secretory proteins is reduced in the glands of the older animals. However, there is no significant difference in the incorporation of $\left[{ }^{14} \mathrm{C}\right]$-leucine into those bands which remain distinct in gel preparations of the IPR-stimulated glands (Kim et al., 1982). These results indicate that the age-related reductions in pro- tein synthesis in parotid gland reflect largely the decline in the synthesis of exportable, secretory proteins.

Despite the reduction in the synthesis of secretory proteins, it does not appear that all aspects of the secretory function of this gland decline with age. The ability of the secretory cells in rat parotid gland to release $\boldsymbol{x}$-amylase upon appropriate stimulations does not seem to change during ageing. Isolated lobules (unpublished observations) or dispersed cell aggregates (Ito. Baum and Roth, 1981) of the gland from young and old rats release $x$-amylase at about the same rate upon incubation with a $\beta$-agonist, isoproterenol. Similarly. Baum (1981) showed that there are no age-related differences in the rate of stimulated parotid salivary flow in men and women, which suggests that $\beta$-adrenergic receptors on the parotid secretory cells remain functionally intact during ageing. This study contradicts the earlier report of the decremental changes in the secretion and flow rate of the saliva in elderly persons (Necheles of al. 1942; Bertram, 1967). This discrepancy probably reflects the differences in the methodology used in measuring the secretion of saliva as well as selecting the samples.

Acknowledgements This study was supported by the Veterans Administration and by Grant $\mathrm{AGO0044}$ from the National Institute of Health.

\section{REFERENCES}

Amsterdam A. Schramm M. Ohad I. Salomon Y. and Selinger Z. 1971. Concomitant synthesis of membrane protein and exportable protein of the secretory granule in rat parotid gland. J. Cell Biol. 50, 187200.

Baum B. J. 1981. Evaluation of stimulated parotid salivat flow rate in different age groups. $J$. dent. Res. 60. 12921296.

Bertram U. 1967. Xerostomia: Clinical aspects, pathology and pathogenesis. Acta odemt. scand. 25, Suppt. 49. $1-126$.

Breuer C. B. and Florini J. R. 1965. Amino acid incorporation into protein by cell-free systems from rat skeletal muscle. IV. Effects of animal age, androgens and anabolic agents on activity of muscle ribosomes Biochemistr 4, 15441550 .

Chilla R.. Niemann H.. Arglebe C. and Domagk (i. F. 1974. Age-dependent changes in the alpha-isoamylase pattern of human and rat parotid glands. ORI. 36 . 372.382 .

Du J. T., Beyer T. A. and Lang C. A. 1977. Protein biosynthesis in aging mouse tissues. Expl Gerontol. 12, 181191. 
Fenner A., Traut R., Mason D. and William-Cotfelt J. 1975. Quantification of Coomassic blue stained proteins in polyacrylamide gels based on analysis of eluted dye. Analy. Biochem. 63, 595-602.

Hrachovec J. P. 1969. Age changes in amino acid incorporation by rat liver microsomes. Gerontologia 15, 52-63.

Johnson T. C. and Belytschko G. 1969. Alteration in microsomal protein synthesis during early development of mouse brain. Proc. natn. Acad. Sci. U.S.A. 62, 844-851.

Ito H., Baum B. J. and Roth G. S. 1981. $\beta$-Adrenergic regulation of rat parotid gland exocrine protein secretion during aging. Mech. Agng Dev. 15, 177-188.

Keleti G. and Lederer W. H. 1974. In: Handbook of Micromethods for the Biological Sciences, pp. 139-142. van Nostrand Reinhold, New York.

Kim S. K., Weinhold P. A., Han S. S. and Wagner D. J. 1980. Age-related decline in protein synthesis in the rat parotid gland. Expl Gerontol. 15, $77-85$.

Kim S. K. 1981. Age-related changes in the cellular level of amylase and protein synthesis in the rat parotid gland. $J$. dent. Res. 60, 738-747.

Kim S. K., Weinhold P. A., Calkins D. W. and Hartog V. W. 1981. Comparative studies of the age-related changes in protein synthesis in rat pancreas and parotid gland. Expl Gerontol. 16, $91-99$

Kim S. K.. Calkins D. W.. Weinhold P. W. and Han S. S. 1982. Changes in the synthesis of exportahle and nonexportable proteins in parotid glands during aging. Mech. Agng Dev. 18, 239-250.

Kurtz D. 1. 1975. The effect of ageing on in vitro fidelity of translation in mouse liver. Biochim. biophys. Acta 407, 479-484.

Layman D. K., Ricca G. A. and Richardson A. 1976. The effect of age on protein synthesis and ribosome aggrega- tion to messenger RNA in rat liver. Archs Biochem. Biophys. 173, 246-254.

Lillie J. H. and Han S. S. 1973. Secretory protein synthesis in the stimulated rat parotid gland. J. Cell Biol. 59, 708-721.

Liu D. S. H.. Ekstrom R., Spicer J. W. and Richardson A. 1978. Age-related changes in protein, RNA and DNA content and protein synthesis in rat testes. Expl Gerontol. 13, 197-205.

Lowry O. H., Rosenbrough N. J., Farr A. and Randall R. J. 1951. Protein measurement with folin reagent. $J$. biol. Chem. 193, 165-175.

Mainwaring W. I. P. 1969. The effect of age on protein synthesis in mouse liver. Biochem. J. 113, 869-878.

Meyer J., Golden J. S., Steiner N. and Necheles H. 1937. The ptyalin content of human saliva in old age. Am. J. Physiol. 119, 600-602.

Meyer J. and Necheles H. 1940. Studies in old age. IV. The clinical significance of salivary, gastric and pancreatic secretion in the aged. J. Am. med. Ass. 115, 2050-2053.

Moldave K.. Harris J., Sabo W. and Sadnik I. 1979. Protein synthesis and aging: studies with cell-free mammalian systems. Fedn Proc. 38, 1979-1983.

Murthy M. R. V. and Rappoport D. A. 1965. Biochemistry of the developing rat brain: $V$. Cell-free incorporation of $\mathrm{L}-\left[\mathrm{I}-{ }^{14} \mathrm{C}\right]$ leucine into microsomal protein. Biochim. biophys. Acta 95, 121 131 .

Necheles H., Plotke F. and Meyer J. 1942. Studies on old age. V. Active pancreatic secretion in the aged. Am. $J$ dig. Dis. 9, 157-159.

Ove P.. Obenrader M. and Lansing A. 1972. Synthesis and degradation of liver proteins in young and old rats. Biochim. biophys. Acta 277, 211-221.

Van Bezooijen C. F. A., Grell T. and Knook D. L. 1977. The effect of age on protein synthesis by isolated liver parenchymal cells. Mech. Agng Der. 6, 293-304. 